Aleksandar Janković*

Bojan Leontijević*

Milan Pašić**

796.332.052.242.093.1(100)"2010"

Veselin Jelušić***

Original scientific paper

*Faculty of Sport and Physical Education, University of Belgrade

**Primary school „Ivo Andrić“ Belgrade

$* * *$ College of Sports and Health Belgrade

\title{
INFLUENCE OF CERTAIN TACTICAL ATTACKING PATTERNS ON THE RESULT ACHIEVED BY THE TEAMS PARTICIPANTS OF THE 2010 FIFA WORLD CUP IN SOUTH AFRICA
}

\begin{abstract}
The aim of this study is to compare tactical manifestations of soccer teams, different competitive success, defined on the basis of the achieved results in one match at the 2010 FIFA World Cup in South Africa. The teams were divided into 3 groups based on the match results, the tactical analysis included a total of 60 matches of 2010 FIFA World Cup in South Africa. The first sub-sample of the subjects (winning) was consisted of the teams that won in the final result, the second sub-sample (draw) were the teams that ended in tied score (no winner), while the third subsample (defeat) consisted of the teams which were defeated in the course of regular 90-minute game. Based on the previously processed data, which were taken from the official website of the International Federation of Association Soccer (www.fifa.com), the observed parameters refer to the game efficiency, tactical attacking resource - passing the ball and the ball passing structure. Based on the analysis of the successful attacks frequency, it was revealed that there is a statistically significant difference in the number of successful attacks between the teams that had achieved different results $(\mathrm{p}=0.003)$, in favor of the winning teams. Additionally, the successfulness of attacks, observed through their accuracy, indicates the differences in their distribution $(\mathrm{p}=0.000)$ between the aforesaid groups. The results also indicate that the total run distance, on the level of one team is not associated with the final result. However, ball possession $(\mathrm{P}=0.001)$, overall number of passes $(\mathrm{p}=0.015)$ and overall number of correct passes $(\mathrm{P}=0.013)$ were figured as important factors in achieving better results, while the analysis of the efficacy percentage and the structure of the game that applied passing, i.e., pass length is little or not associated with the final result. The results of this study can help identify those tactical attacking resources in soccer, which contribute to achieving better results.
\end{abstract}

Key words: SOCCER / GAME ANALYSIS / TACTICS / RESULT / PASSING

\section{INTRODUCTION}

Tactics in soccer is an important factor in preparing the team or individual for the competition. The lack of tactical preparation and strategy development is one of the main reasons for poor performances and results of one team (Ali, 1998). Tactics of attack is a part of an overall strategy and plays an important role in soccer game. Numerous studies have focused on the analysis of offensive action in the game, because scoring a goal is the main objective of the game. Goals and shots on goal are the key elements that de- 
termine the success or failure of the soccer team. It is necessary to shoot and score in order to win in soccer match (Hook and Hughes, 2001).

Statistical analysis of the game, given the individual, group and team technical and tactical elements, is one of the ways that can be used for describing and monitoring the tactical manifestations and results in the competition. However, more detailed analyses of matches are more objective ways of viewing tactical activities during the match (Carling et al., 2005).

An efficient way to identify basic elements of successful result achieving is to identify the quality and quantity of technical and tactical actions by the players of both the winning and the defeated teams in direct competition (Szwarc, 2004). Performance indicators are defined as the selection and connection of the monitored parameters that define particular performance aspects, based on which better results can be achieved. Despite the limitations that may arise, when making conclusions, derived pursuant to this kind of study, this type of data is useful for the purpose of monitoring and forecasting of soccer game development in the field of tactics.

In previous studies related to the analysis of soccer matches, most researchers have focused on the analysis of the scored goals and activities that have led to shots (successful attacks) in the major competitions - world and continental championships (Jankovic et al., 2009; Szwarc, 2008; Jankovic and Leontijević, 2007, Acar etal., 2007; Luhtanen et al., 2001), and then in the best club-level competitions (Buraczewski and Cicirko, 2007; Szwarc, 2007; Bergier and Buraczewski, 2007). A number of studies tried to find a causal link between individual statistical indicators and the achieved results (Lago et al., 2010, Rampinini et al., 2009, Armatas et al., 2009), while some authors tried to identify differences between successful and unsuccessful teams in different representative, club-level and national competitions when organizing successful attacks, as well as in the structure and efficiency of passes (Hughes and Franks, 2005, Jones et al., 2004; Szwarc, 2004; Hook and Hughes, 2001, Grant et al., 1999, Hughes et al., 1988). A number of papers have analyzed the structure and efficiency of technical manifestation of soccer players in the top soccer competitions (Jankovic and Leontijević, 2009, 2008; Rampinini et al., 2009).

The results of these studies indicate the differences in the playing characteristics of the teams that achieve different results. The playing differences are primarily reflected in greater efficiency of shots on goal, as well as in application of passes of the teams which score better results. However, few analyses included both the aforementioned parameters, while it was noticed that a negligible number of papers explored in detail the performance and structure of passes as direct indicators of achievement of either positive or negative results. World Cup in South Africa (SP JAR), as representative of modern top soccer, can offer a more accurate answer to, yet unknown relationship between tactics and soccer results.

Therefore, due to a small number of studies related to tactical demonstration of soccer teams, with different levels of performance, defined based on the final result, a need arose for this kind of research. It is necessary to determine whether and to what extent there are differences in application of certain tactical resources between the teams that have achieved different results at the end of soccer matches, i.e., that can be said to be successful or unsuccessful. Also, few studies, dealing with these problems, managed to identify technical and tactical aspects of the game and subsequently to find their relationship with the result.

The subject of this research was to reveal and track tactical validity to achieve better result in soccer game. The subject included spatial tactical manifestation of soccer teams, through the analysis of structure of those attacks that resulted in shoots on opponent's goal, as well as the passing structure. Tactical manifestation, primarily implies technical and tactical activities that an individual, group of players or the whole team undertakes in order to, depending on the part of the field, perform by tactical patterns, rational and efficient actions to score a goal.

The aim of this paper was to compare tactical manifestations of soccer teams of ifferent levels of performance defined on the basis of the achieved results in a regular 90-minute game without overtime, at the 2010 FIFA World Cup in South Africa. Specifically, it is necessary to determine whether and to what extent there are differences in application of 
some tactical resources in organization of successful attacks as well as to determine whether it is statistically allowed to classify the teams at the World Cup into winning, those who ended in tied score and defeated.

\section{METHODS}

\section{Sample of subjects}

60 matches of the 2010 FIFA World Cup in South Africa were analyzed in this research i.e., the games that lasted 90 minutes without overtime. The teams were classified in three groups of subsamples based on the achieved result at the end of the match. The first group of subsamples (victory) consisted of the teams that won in the final result, the second subsample of the subjects (draw) included the teams which ended the match in a tied score (no winner), while the third subsample (defeat) comprised the teams which were defeated in the regular 90-minute game.

\section{Procedure}

In the analysis of the previously elaborated, overall of 60 matches of the 2010 World Cup in South Africa, the observed parameters were taken from the official FIFA site (www.fifa.com), related to the game efficiency, game with application of passes as well as the passing structure. For the purposes of this paper, we analyzed the data, which directly affected the final result of a soccer match, attacking activities of the participating teams, i.e., shots on goal and passes of the teams participating in the 19th World Cup.

\section{Variables}

The variables that were monitored, were selected as the primary for the subject analysis and as such resulted from basic theoretical, practical principles, pertaining to soccer game and its evolution. This paper's researching attention is directed at observation of successfully organized attacks which resulted in tactical resource of shot on goal, as well as characteristics of the game with application of passes, ball possession and structure (length) alone of passes.

The overall number of successful attacks at one match presents the first variable explaining the cor- relation of the results and technical-tactical performance of the teams. The second variable, is defined as efficacy of successful attacks and it is analyzed through accuracy shots on opponent's goal, differentiating accurate attacks (shots in the goal frame), inaccurate attacks (shots outside the goal frame) and efficient attacks (goals). While the third variable is passing, i.e., volume and efficiency of the game with application of passes in the course of match (ball possession, overall number of passes, number of correct passes, percentage of correct passes, as well as features of the game alone with application of passes short, medium and other passes).

\section{Statistical data processing}

Standard descriptive statistical analysis (overall and medium value, as well as standard deviation) was calculated for every variable. From the space of comparative statistics, a non parametric variance analysis was used, as well as Kruskal-Wallis test, which determined the differences between medium values of frequencies in certain variables, as well as Mann-Whitney test which explained more accurately possible differences. Chi-square test was used to detect correlation between the team results and distribution of the variables within the observed parameters. The level of statistical significance was on $p<0.05$. All statistical tests were processed by using SPSS 17.0 program (SPSS INC, Chicago, IL).

\section{RESULTS AND DISCUSSION}

The aim of this study was to identify the relationship between tactical manifestation and achieved results of the teams that competed in the 2010 World Cup in South Africa. Considering the fact that soccer result is determined by a large number of factors, one group of authors believe that this approach in the analysis of game efficiency, must be taken with a grain of salt (Lago, 2009, Taylor et al., 2008). However, such an observation may indicate to certain principles that can be used in the analysis of the soccer game structure, and what is very important, the results obtained in this study have direct practical implications, both in training technology, and in direct preparation for competition. 
At the $19^{\text {th }}$ World Cup in South Africa, 32 teams participated, divided into eight groups in the first phase. 48 matches were played in the group phase, 34 of which were finished with victory of one national team, while 14 games ended tied. 16 matches were played in the elimination phase and overtime was played at 4 of them, so they were not included in the analysis, because of the the validity of the obtained results. With this paper we have obtained the data that suggest an association of the results and tactical manifestations of the teams whose playing characteristics were analyzed.

Table 1 Comparative analysis of the average number of successful attacks of the teams per match in 2010 World Cup depending on the achieved results.

\begin{tabular}{|lccc}
\hline Successful attack & winner & draw & lose \\
\hline Average & 16.02 & 12.07 & 12.72 \\
Stdev & 5.46 & 5.36 & 4.68 \\
Asymp. Sig. & & $0.003^{*}$ & \\
Mean Rang & 74.25 & 49.82 & 53.25 \\
Chi-Square & & 11.872 & \\
\hline
\end{tabular}

Based on the number of successful attacks during the match (those attacks that resulted in a shot on the opponent's goal) and when comparing their frequencies, a significantly lager number of such attacks can be observed in the teams that have made better results, and were much better ranked $(\mathrm{p}=$ 0.003) (Table 1). These data, though quite expected, indicate that teams which achieve better results take the initiative and win by having better attack organization than their opponents. Greater number of shots on goal are more likely to finish in scoring, but it also implies a certain relation in the field between the two opponents. When analyzing 2002 World Cup Szwarc (2004) obtained similar results and according to them the finalists had on average 18 shots on goal, which is more than the teams that had not come to the finals (average of 14.08 shots). Grant et al. (1999) obtained the data, when analyzing the 1998 World Cup that successful teams achieved an average 18.1 shots on goal, while the unsuccessful teams achieved about half the shoots 9.5. Additionally, Hughes and Franks (2005) compared the effectiveness of tactical activities between successful and unsuccessful teams at the 1990
World Cup and also obtained the results according to which more successful teams realize greater number of shots on goal than the unsuccessful ones. Roxburg (2008), presented the facts that at the 2008 European Championship, the semi-finalists performed an average of 15 successful attacks per game, while the last four ranked teams in the group achieved an average of 13.2 a successful attacks. In the 2009/10 season in the Champions League the teams that qualified for quarterfinals had on average 13:13 successful attacks, and the last eight ranked teams in the group only 8.76 attacks, while in the League of Europe, the secondbest European club-level competition, teams in quarterfinals had an average of 11.99 successful attacks, and eight of the last ranked teams in the group phase of the competition an average of 9:38 attacks. (www. uefa.com). Based on the analysis of the Spanish professional league (current world champion), results of the winning teams, an average of 14.4 shots on goal have been recorded, the teams that tied 13.6, while the defeated team an average of 12 shots on goal, as indicated by the data provided by Lago et al. (2010). Similar results were obtained by the analysis of the Greek soccer championship (Armatas et al., 2009), as well as the Italian „Serie A” (Rampinini et al., 2009). Janković et al. (2009) analyzed the number of successful attacks of the four best teams in three previous World Cups $(1998,2002 ; 2006)$ and came to the conclusion that the average number of successful attacks at $16^{\text {th }}$ World Cup was 17.68 , at the $17^{\text {th }}$ World Cup 11:46, while it was only 10.96 attacks at the $18^{\text {th }}$ World cup. The above stated results clearly indicate that much more attention is required for the game analysis and within that analysis to attack tactics, i.e., methodology of the efficient attack organization.

As a continuation of attack tactics analysis, besides the frequency of successful attacks, accuracy of the final shots on goal is essential. All shots directed at the opponent's goal, according to generally accepted classification, are divided into precise and imprecise, and the scored goals are defined as the effective shots. In relation to this approved indicator, the results of the study show that there were significant differences $(p=0.000)$ in distribution of different accuracy shots in teams which achieved different results (Graph 1). Janković et al. (2009) analyzing the accuracy of successful attacks of the four best teams in three World Cups (1998, 2002, 2006), 
came to the data that the average number of imprecise attacks at the $16^{\text {th }}$ World Cup was 10.61 , at the $17^{\text {th }}$ World Cup 6, while at the $18^{\text {th }}$ World Cup it was 5:36 attacks, while there were 5.21 precise attacks at the $16^{\text {th }}$ World Cup, 3.68 at the $17^{\text {th }}$ World Cup and
4.14, at the $18^{\text {th }}$ World Cup, while the number of effective attacks was 1.86 at the $16^{\text {th }}$ World Cup, 1.79 at the $17^{\text {th }}$ and 1.5 at the $18^{\text {th }}$ World Cup. These data clearly indicate that the total number of successful attacks decreases.

Graph 1 Analysis of the accuracy of successful attacks and their distribution depending on the acquired result at the 2010 World Cup expressed as mean values for one game.

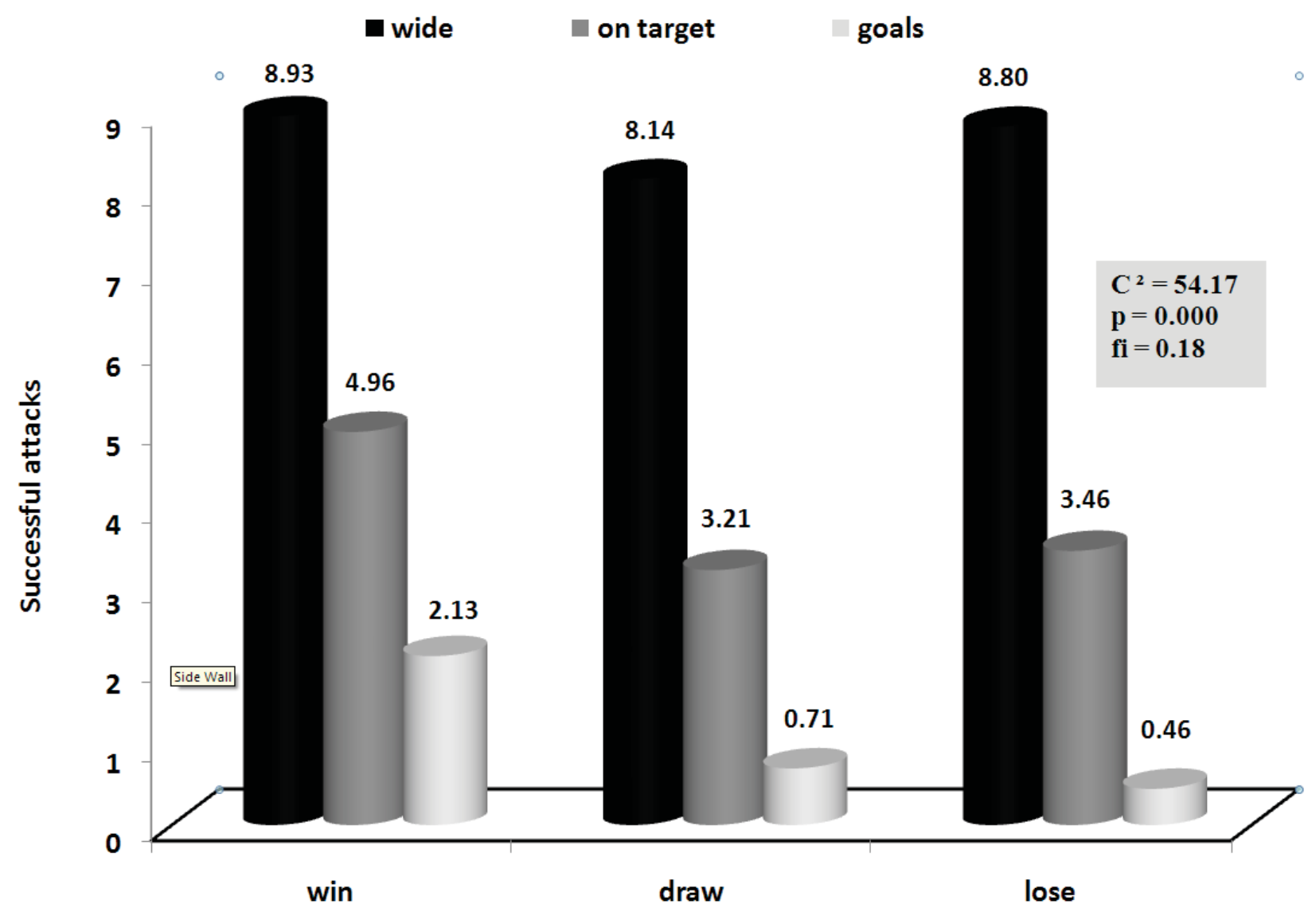

Based on the results of the analysis it can be concluded that the winning teams achieved a higher percentage of effective attacks compared to less successful teams. Additionally, it can be noted that all three subsample groups have an equal number of accurate shots, while the defeated and the teams that tied have far higher percentage of imprecise shots (Graph 1). These differences in distribution of shots of different precision can be explained by quality individuals who realize attacks in the winning teams, but also with the distance from which the final shots are directed.

Lago et al. (2010) concluded that the winning team shot more on goal than the defeated and the team who tied in the Spanish professional league. Also, winning teams had higher efficiency than the teams that were defeated and those which finished their matches tied $(46.17 \%, 37,545$, and $35.57 \%$, respectively). Within the group of winning teams relationship of goals and shots was 1:7.5 (each seven shots result in one goal) in the group of tied games it was $1: 17$, while in the group of the defeated teams the ratio was $1: 27.65$, from this we can see that successful teams have a higher percentage of effectiveness (realization) from other teams. Roxburg (2008) by analyzing the 2008 European Championship, obtained data that the teams semi-finalists, had a ratio of 1:9, while the last four ranked teams in the group had 1:28, while Hook and Hughes (2001), stated that at the 2000 European Championship, the ratio of suc- 
cessful teams was $1: 7$, and 1:17 of the unsuccessful. Szwarc (2007) when analyzing the final Champions League came to the ratio of $1: 8$ of the teams that won the Champions League and 1:24 of the defeated teams. These data indicate that more successful teams better realize given opportunities to score and have a higher percentage of realization, which is also one of the prerequisites for good results. Analyzing the teams of the Italian „Serie A” significant differences were observed between the first five teams on one hand, and the last five teams on the other hand, in terms of accurate shots, in favor of the more successful teams (Rampinini et al., 2009). Also, Armatas et al.(2009) concluded that in more successful teams, relationship of goals and shots on goal was 1:7.8, while in the two bottom ranked teams the ratio was $1: 14.2$.

From this and from previous researches it can be concluded that the difference between winning and defeated teams is mostly evident in shots on goal and in the efficiency of those shots on goal (Grant et al. 1999). Observed through individual examples, it often happens that the team which shoots less on goal than its opponent achieves victory, but special value of this research reflects in a large number of analyzed matches, $94 \%$ of all games played at the world cup, so the obtained results provide reliable indicators of the tactical efficiency of the teams participants. The results of this study certainly indicate that the teams that achieved victory more effectively organize their attacks, which provides them more probable situations to score a goal but also to dispose with more quality attackers when compared to the defeated and the teams that ended their games in a draw. However, the Italian national team, the winner of 2008 World Cup, compared to seven teams with whom they played, did not differ in total number of shots on goal, or in distribution of shots of different precision (Acar et al., 2007).

Physical fitness in today's soccer is one of the most important parameters that can influence the outcome of soccer matches. Based on results of this analysis, it can bee seen that there is no significant difference between the three $\mathrm{WC}$ team groups in relation to the total distance covered by the whole teams (Table 2), where all the teams ran on average about $105 \mathrm{~km}$ per match, or about 10.500 meters per player. These data show that it is not enough to be physically more prepared than your opponent, but it is necessary to change, by adequate tactical plan, the rhythm and dynamics of the game in order to surprise the opponent by surprise. The lack of the data may be that we do not know in what intensity zones these movements were realized and the distance covered by players playing in different positions. As well as, which is extremely important for understanding the tactics of soccer game, how the ratio of covered kilometers varied depending on the result, and even on the immediate possession of the ball and certain situations in the game.

Table 2 Comparative analysis of the structure and successfulness of the game with passings game, and covered distance (of the whole team) at the 2010 World Cup between the teams that realized different results, expressed as average values per match

\begin{tabular}{cccccccc}
\hline & \multicolumn{2}{c}{ WIN } & \multicolumn{2}{c}{ DRAW } & \multicolumn{2}{c}{ LOSE } & \multirow{2}{*}{$\boldsymbol{p}$ (value) } \\
\cline { 2 - 6 } & Average & stdev & Average & stdev & Average & stdev & \\
\hline DC & 105.2 & 6.3 & 105.8 & 5.1 & 103.6 & 5.7 & 0.200 \\
\%PT & $52.3^{*}$ & 6.0 & 50 & 5.3 & 47.6 & 6.0 & 0.001 \\
SP & $533.5^{* *}$ & 114.7 & 480.8 & 95.8 & 473 & 94.4 & 0.015 \\
PC & $391.6^{*}$ & 115.3 & 342.1 & 99.1 & 331.9 & 88.5 & 0.013 \\
\%PCR & 72.3 & 7.1 & 69.9 & 7.5 & 69.2 & 6.9 & 0.108 \\
\hline
\end{tabular}

DC - overall covered kilometers per team; PT\% - percentage value with regard to ball possession; PC - overall number of sufficient passes per game; PCR (\%) - percentage of successfulness of passes; * significantly more than the defeated team; $* *$ significantly more even than the defeated and teams who played tied; for $\mathrm{p}<0.05$ (Kruskal-Wallis test) 
Positive ball possession in soccer is a desirable option, but without real technical quality this approach increases the risk of counterattack, and sometimes leads to recombining and lack of a finish (Roxburg, 2008). Analyzing the data, referring to the ball possession, in table 2 , it can be noted that the winning teams realized significantly higher ball possession than the defeated teams $(p=0.001)$. Such data mean that the teams which manage to control the game, by significantly higher ball possession than their opponents, also score better results. Comparing the successfulness of tactical activities between successful and unsuccessful teams at the 1990 World cup Hughes and Franks (2005) found the differences between these two groups of teams, where more successful teams had better indexes compared to ball position. Additionally, Hook and Hughes (2001) established that successful teams have better possession than the unsuccessful teams at the 2000 World Cup. The authors proposed that keeping the ball in possession is indicative for success. Analyzing tactical activities of the French national team, world and European championship at that moment, Japheth and Hughes (2001) stated that France was capable to produce much more shots, and also had ability to keep the ball in possession for a longer time, compared to their opponents. Jones et al., (2004), analyzing the English Premier league, reached the data that successful teams have greater ball possession than the unsuccessful ones. All the aforesaid results undoubtedly indicate that it is necessary to keep the ball in possession for longer time than for better scoring it is necessary to keep a ball in possession for longer time and thus impose its own playing style, however Lago (2007), when analyzing Spanish professional league Primera, found the data, according to which the defeated teams had significantly greater ball possession than the teams who tied or won. These results are certainly supported by current events and results but at club and national team levels, which indicate the domination of teams which cherish attacking game, i.e., have longer ball possession than their opponents. The real representative of such game pattern is certainly FC Barselona as well as the Spanish national team, current Europe and world. Per their dominance on tactical plan and technical activities with ball, certain number of national teams, particularly Spain, the Netherlands and Germany imposed at the World Cup their game to their opponents and with distinct performance used the advantages of ball possession.
Taking into account the fact that acceptancerelease of the ball is the basic unit of cooperation between two teammates and that on its efficiency, the efficacy of attacking tactic of one team depends, the relation of overall number of passes and overall number of correct passes represents an essential index of playing efficiency in the field of one team. Modern soccer, requires soccer players with high percentage of correct passes, especially in the maneuvering space and under pressure of the opponent's players. Taking into consideration play in narrow marking in every part of the field, primarily technical training of the players, is manifested, as well as the ability to control the ball in the most complex game situations (Janković et al. 2009). Observing the overall number of passes of the teams participating in the 2010 World Cup, it can be seen that there are significant differences $(p=0.015)$ in the average number of passes during the match, and from the analysis it can be observed that the winning teams have significantly more passes than the defeated teams, and than the teams that tied (Table 2.). Such a result is added to the existence of differences in the time of ball possession, but significantly more passes of the winning teams with regard to the remaining two groups indicates that the winning teams play also in simpler way, faster with shorter keeping of the ball in possession by the players. Analyzing the season 2009/10 of the Champions League in the elimination phase of the competition the average of overall passes was 459.2 (www.uefa.com), while the finalists of this competition realized on average 478 passes and their opponents during the competition, 305.5 (Szwarc, 2007). The ratio of number of passes in the final match, of the mentioned competition, was 716 - FC Barselona as the winner and 307 for FC Arsenal as the defeated in this match (Zubillaga et al. 2007). Szwarc (2004) presented the analysis of the number of passes of the finalist teams of the $17^{\text {th }}$ World Cup 2002 and their opponents in their duels, where the finalists realized on average 355.16 tries of passes, and their opponents on average 387.58 passes.

When it comes to the number of correct passes, it can be noted also, a greater number of more successful passes in those teams which achieve better results (Table 2). Additionally, there is a significant difference between the winning teams and those who lost at the end of the match $(\mathrm{p}=0.013)$. In the season $2009 / 10$ of the Champion league in the elimination 
phase of the competition, the average of number of successful passes was 328.1 (www.uefa.com). At the European Championship 2008 successful teams, i.e., those who moved to the second phase of competition had on average 359.9 successful passes, while the teams who did not move to the elimination phase of the competition had on average 217.4 successful passes (www.uefa.com). The teams winners of the Champion League had on average 362.14 passes while their opponents realized 234.43 passes (Szwarc, 2007). Grant et al. (1999) presented the data, according to which, the successful teams realized an average of 362.7 correct passes, and the unsuccessful ones only 308.9 at the 1998 World Cup. The teams finalists of the $17^{\text {th }}$ World Cup 2002 had an average of 292.75 passes while their opponents realized 314.67 passes (Szwarc 2004). Comparing the results of this analysis with the data of the previous researches it can be concluded that the greatest number of correct passes was recorded at the last World Cup by the winning teams, on average 391.6 (Table 2).

When it comes to the percentage of correct passes, i.e., game efficiency with application of passes, it can be seen that there is no statistically significant difference among the teams with regard to the final result ( $\mathrm{p}=0.108$ ) (Table 3.). Pursuant to these results, the conclusion is that the teams pretending to high ranking, must primarily have quality individuals, i.e., dedicate more attention, in training process, to technical-tactical training of their players, because their game efficiency directly affects the result realized by the team. In the season 2009/10 of the Champion league, in the elimination phase of the competition, the percentage of successfulness of passes was 70\% (www.uefa.com). At the 2008 European Championship, the successful teams, i.e., those who moved into the second phase of the competition had a successfulness percentage of $75.6 \%$, while the teams who did not move in the elimination phase of the competition had 72.4\%. (www.uefa.com). However, Zubillaga et al., (2007), when analyzing the finals of the Champions league reached the result that the team of FC Arsenal, which had one goal of advantage in the firs term, had the percentage of successfulness $78 \%$, and Barselona $85 \%$, while in the second term, when Barselona changed the the result and celebrated in that match in the second 45 minutes its percentage of successfulness was $89 \%$, while Arsenal had only $62 \%$.

Analyzing the game structure with application of passes, depending on the length of passes, and its influence on the realized result, it can be seen that there is no statistically significant difference in successfulness of passes, of different length, among the teams which achieved different results (Graph 2). Observing, percentage-wise, the teams apply most the medium-length passes (63\%), followed by short passes $(24 \%)$ while the longest passes are least applied $(13 \%)$. With regard to application of these types of passes there is no difference in their distribution with these three groups of teams, therefore, the teams, independently of the realized result use equally short, medium and long passes. Scoulding et al. (2004) when analyzing the passes at 2002 World Cup, also found out that there were no significant differences in the length of passes between successful and unsuccessful teams. However, Rampinini et al. (2009) when analyzing successfulness in the Italian professional league Serie A, found out that successful teams differ significantly in the overall number of short passes and by successful short passes with regard to unsuccessful teams. 
Graph 2 Percentage of successfulness of short, medium and long passes depending on the realized result.

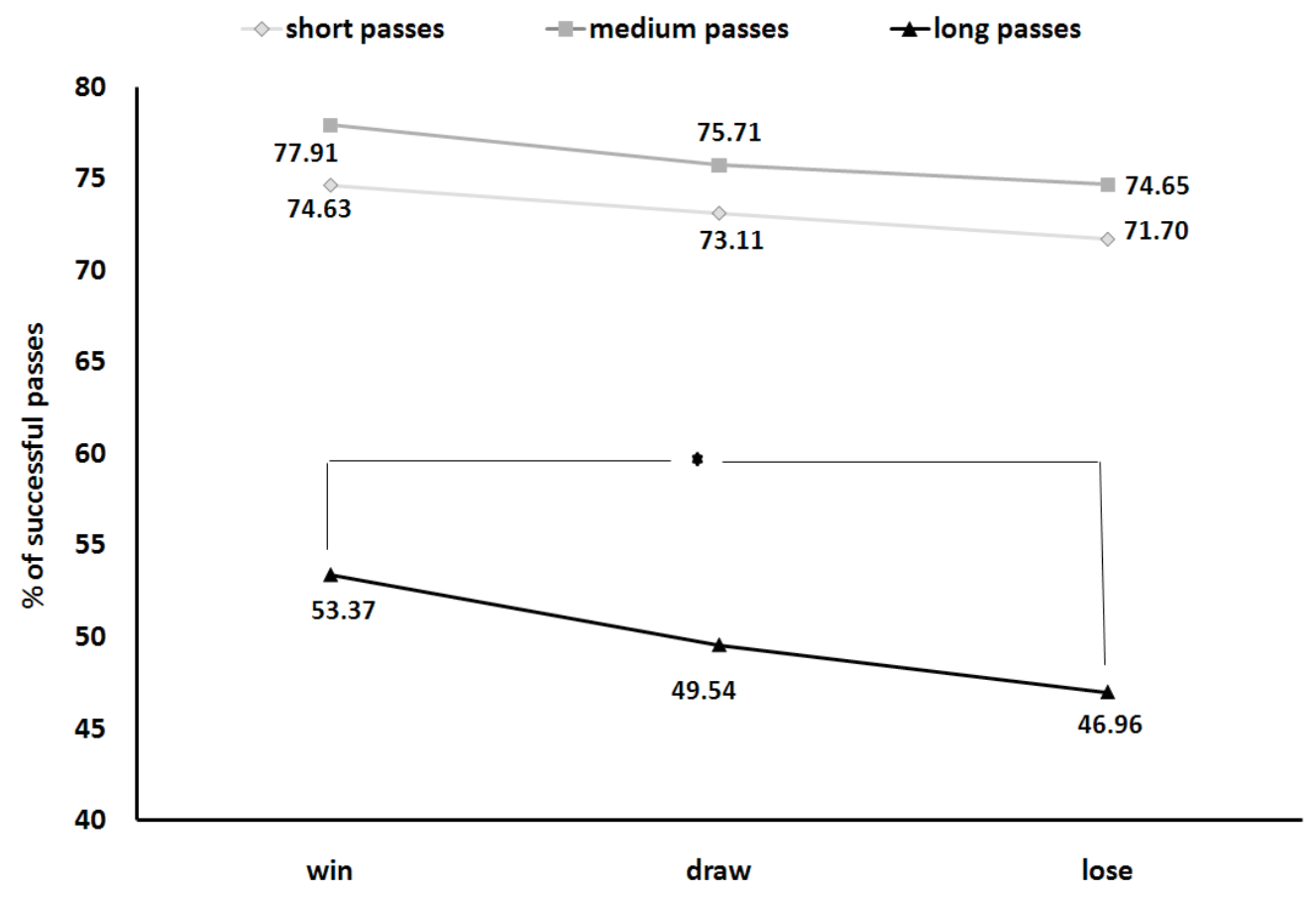

*significantly higher percentage of correct, long passes of the winning teams compared to the defeated teams

When it comes to the efficiency of passes of different length, Graph 2 displays that teams have approximately equal successfulness when realizing short and medium passes, with the efficiency of medium passes ranging between $74 \%-78 \%$, and short passes efficiency from $71 \%-75 \%$, with an unexpected conclusion that national teams were more precise in medium passes compared to short distance passes. However, from Graph 2 it can be seen that the winning teams, when realizing long passes had significantly higher percentage of successful, long passes compared to the defeated teams. From these results we cannot claim with certainty that the teams have won thanks to more precise long passes, but it can be an important element of soccer play tactics, where with carrying balls, the center of the game is easily changed and slower moving of opponents in defense is used in the game. Precise long passes have special value even in shots from center form winger positions as well as in situations of game breaks, through which, according to the latest research, over $50 \%$ of all goals are scored.

Although such researches investigate success indicators in soccer, some restrictions or method- ological problems in the examining these studies can be observed. Many of these studies did not succeed to show reliability for data collection of the used system (Hook and Hughes, 2001). Additionally, the results should be taken with care, because the results were obtained through the analysis on a limited number of teams, representative level and as such cannot be valid for other competitions. It is necessary, in next papers, to compare game efficiency of the national and club - level teams, of course with regard to the achieved result. The continuity of follow-up of influence of certain tactical solutions shall provide identification of rational and efficient tactical variants.

\section{CONCLUSION}

Technical-tactical activities are exceptionally important segment of soccer game structure, and having in consideration that in modern, top soccer, the only measure of value is the result, therefore quantifying of all the activities of individuals, group of players or even of the entire team, which contrib- 
uted to achievement of top sports result is essential in programming and management of the training process of any team..

The differences between winning and defeated teams are mostly evident in frequency and efficiency of shots on goal as well as in success of passes (Grant et al., 1999). The results of this analysis, confirm to the great extent the outcome of previous studies, but also indicate to distribution of the variables in certain, observed parameters, and reveal their relationships based on the achieved result.

By analyzing correlation of tactical manifestation and the achieved result, based on monitoring of matches at 2010 World Cup in South Africa, the following conclusions can be made:

- Based on the number of successful attacks (shots on goal), it was confirmed that there is a statistically significant difference in the average number of successful attacks between the teams which achieved different results, and that difference is in favor of the winning teams.

- The results of the successful attacks analysis and their classification into accurate, inaccurate and efficient attacks, confirm the results of previous researches that the final outcome in a big competition, such as 2010 World Cup in South Africa, depends on the number of performed attacks.

- The overall run distance per subsamples is not connected to the final results, since there is no statistically significant difference in achieving the final result.

- Based on the possession of ball it was confirmed that there is no statistically significant difference in the percentage of possession between the teams which achieved different results, and that difference is in favor of the winning teams.

- The teams that won significantly differ also when compared to other two groups, with regard to an overall number of passes, as well as to number of successful passes realized in the 2010 World Cup in South Africa.

- However, by analyzing the percentage of accurate passes, it can be observed that there is no statistically significant difference between the teams based on the achieved result.

- By analyzing the structure of passing i.e., coach's tactical commitment, it can be seen that there is no statistically significant difference in application of passing of different length between the three analyzed groups, but when it comes to efficiency of different length passing, the winning teams were substantially more successful in long passes, while the success of short and medium passes is approximately equal.

The paper presented the values that can be used as normative data for projecting and assessment of competitive activity of soccer teams, top performances in a collective way. However, the results reached by this analysis are specific and they reflect events at the current moment, with all specificities of the competition, importance of the games, representative teams, and as such cannot be generalized so no conclusions should be made based on them related to soccer game tactics on the global level.

Some further analysis, which shall use this study as theoretical framework, should find relations in the game tactics, attack or defense, between the most successful teams on representative continental competitions, i.e., international club-level or national championships, which directly or indirectly affect the result in soccer.

\section{Practical application}

The value of the data related to the game analysis, regardless of their significance, can serve as feedback information for coaches when planning and programming training activities, but not as the only source of information of competitive performance of individuals or the team. Application of the results, generated by such analyses, is primarily reflected in theoretical sense, where based on these results, one can perceive more accurately, certain tendencies in soccer tactics development, but also forecast the direction of further development of certain tactical aspects both in soccer offense and defense. Additionally, from the aspect of practice and technological process, the information provided in such studies are multiply useful in identification of efficient resources of soccer tactics, as well as of implementation of certain elements of technique which contribute to achievement of top soccer results. 


\section{REFERENCES}

1. Acar, M., Yapicioglu B., Arikan, N., Yalcın, S., Ates, N. \& Ergun M. (2007). Analysis of goals scored in 2006 World Cup. In Reilly and Korkusuz. Proceedings from: Science and football VI: Sixth World Congress on Science and Football (235-242). Oxon: Routledge.

2. Ali, A. (1988). A statistical analysis of tactical movement patterns in soccer. In Science and Football, (Eds Reilly, T., Lees, A., Davids, K., Murphy, W.J.) E. \& F. Spon, London, pp 302-308.

3. Armatas, V., Yannakos, A., Zaggelidis, G., Skoufas, D., Papadopoulou, S. \& Fragkos, N. (2009). Differences in offensive actions between top and last team in Greek first soccer divison. A retrospective study 1998-2008. Journal of Physical Education and Sport, 23(2), 1-5.

4. Armatas, V., Yiannakos, A., Papadopoulou, S. \& Skoufas, D. (2009). Evaluation of the goals scored in top ranking soccer matches: Greek "Superleague", 2006-07. Serbian Journal of Sports Sciences, 3(1), 39-43.

5. Buraczewski, T. \& Cicirko, L. (2007). Chosen elements of actions resulting in goals in football matches of the highest rank. Moloda Sportivna Nauka Ukraine, 3, 67-71.

6. Bergier, J. \& Buraczewski, T., (2007). Analysis of successful scoring situations in football matches. Journal of sports science \& medicine, 6(10), 199-209.

7. Carling, C., Williams, A.M. \& Reilly, T. (2005). Handbook of soccer match analysis. A sistematic approach to improving performance. London: Routledge

8. Grant, A.G, Williams, A.M, \& Reilly, T. (1998). An analysis of the successful and unsuccessful teams in the 1998 World Cup. Insght. The F.A. Coaches Association Journal, 2, 21-24.

9. Hook, C. \& Hughes, M. (2001). Patterns of play leading to shots in 'Euro 2000'. In: Pass.com. Ed: CPA (Center for Performance Analysis). Cardiff: UWIC. 295-302.

10. Hughes, M. \& Franks, I. (2005). Analysis of passing sequences, shots and goals in soccer. Journal of Sport Sciences, 23(5), 509-514.
11. Hughes, M., Robertson, K. \& Nicholson, A. (1988). Comparison of patterns of play of successful and unsuccessful teams in the 1986 World Cup for soccer. In: Science and Football. Eds: Reilly, T., Lees, A., Davis, K. and Murphy, W.J. London: E. and F.N. Spon. 363-367.

12. Janković, i A., Leontijević, B. (2007). Uporedna analiza u brzini izvođenja brzih napada u fudbalu (na primeru Evropskih i Latinoameričkih reprezentacija). [Comparative analysis of the performance of fast attack in soccer (for example, European and Latin American teams]. U N. Živanović (ur.). FIS Komunikacije [In N Zivanovic (ed.) FIS Cominacation] (97-107), Niš: FFK.

13. Janković, A. i Leontijević, B. (2008). Structure of technical-competitive activity in modern football. Физичка култура, 62(1-2), 159-179.

14. Janković, A. \& Leontijević, B. (2009). Analysis of application of certain technical elements in soccer depending on the team position. Физичка култура, 63(1), 89-101.

15. Janković, A., Leontijević, B. \& Mićović, B. (2009). Tendencije razvoja taktike igre $\mathrm{kroz}$ analizu uspešnih napada na XVI, XVII i XVIII Svetskom prvenstvu $u$ fudbalu. [Trends in development of tactics through analysis of successful attacks on the XVI, XVII and XVIII World Championships] U V. Koprivica i I. Juhas. Zbornik radova sa: Teorijski, metodološki i metodički aspekti takmičenja i pripreme sportista [In V. Koprivica i I. Juhas (eds.) Proccedings from international confrence: Theoretical, methodological and methodical aspects of competitions and atheletes preperation] (115-121). Beograd: FSFV.

16. Japheth, A. \& Hughes, M. (2001). The playing patterns of France and their opponents in the World Cup for association football, 1998, and the Championships, 2000. In M.D. Hughes \& I.M. Franks (Eds.), Pass.com: Computer Science and Sport III \& Performance of Sport V (pp.277284). Cardiff: University of Wales Institute.

17. Jones, P., James, N. \& Mellalieu, S.D. (2004). Possession as a Performance Indicator in Soccer. 
International Journal of Performance Analysis in Sport, 4(1), 98-102.

18. Lago, C. (2009). The influence of match location, quality of opposition, and match status on possession strategies in professional association football. Journal of Sports Sciences, 27(13), $1463-1469$.

19. Lago, C. \& Martin, R. (2007). Determinants of possession of the ball in soccer. Journal of Sports Sciencess 25(9) 969 - 974.

20. Lago, C., Lago, J., Dellal, A. \& Gomez, M. (2010). Game-related statistics that discriminated winning, drawing and losing teams from the Spanish soccer league. Journal of Sports Science and Medicine, 9(2), 288-293.

21. Luhtanen, P., Belinskij, A., Häyrinen, M. \& Vänttinen, T. (2001). A comparative tournament analysis between EURO 1996 and 2000 in soccer. International Journal of Performance Analysis in Sport, 1(1), 74-82.

22. Rampinini, E., Impellizzeri, F.M., Castagna, C., Coutts, A.J. \& Wisloff, U. (2009). Technical performance during soccer matches of the Italian Serie A league: Effect of fatigue and competitive level. Journal of Science and Medicine in Sport, 12(1), 227-233.

23. Roxburg, A. (2008). Technical report EURO 2008. Nyon: UEFA's Football Development Division.
24. Scoulding, A., James, N. \& Taylor, J. (2004). Passing in the soccer World Cup 2002. International Journal of Performance Analysis in Sport, $4(2), 36-41$.

25. Szwarc, A. (2004). Effectiveness of Brazilian and German teams and the teams defeated by team during the 17th FIFA World Cup. Kinesiology, 36(1), 83-89.

26. Szwarc, A. (2007). Efficacy of Successful and Unsuccessful Soccer Teams Taking Part in Finals of Champions League. Research Yearbook, 13(2), 221-225.

27. Szwarc, A. (2008). The Model illustrating the efficiency of actions in the soccer game. Research Yearbook. Medsportpress, 14( 2), 74-77.

28. Taylor, J.B., Mellalieu, S.D., James, N. \& Sheraer, D. (2008). The influence of match location, qualify of opposition and match status on technical performance in professional association football. Journal of Sports Sciences, 26(9), 885-895.

29. Zubillaga, A., Gorospe ,G. Mendo, A. H. \& Villasenor, A.B. (2007). Match analysis of 2005-06 Champions League Final with Amisco system, (abstract). Journal of sports science \& medicine, $6(10), 20$.

30. www.uefa.com (17. September 2010.)

31. www.fifa.com (24. September 2010. ) 
Александар Јанковић*

Бојан Леонтијевић*

Милан Пашић**

796.332.052.242.093.1(100)"2010”

Веселин Јелушић***

Изворни научни чланак

*Факулгтет спорта и физичког васпитања Београд

**ОШ „Иво Андрић“ Београд

***Висока спортска и здравствена школа Београд

\title{
УТИЦАЈ ПОЈЕДИНИХ НАПАДАЧКИХ СРЕДСТАВА ТАКТИКЕ НА ОСТВАРЕНИ РЕЗУЛТАТ ЕКИПА УЧЕСНИЦА СВЕТСКОГ ПРВЕНСТВА У ФУДБАЛУ У ЈУЖНОАФРИЧКОЈ РЕПУБЛИЦИ 2010. ГОДИНЕ
}

\begin{abstract}
Сажетак
Циљ студије је био да се упореди тактичко испољавање фудбалских репрезентација, различите такмичарске успешности, дефинисане на основу оствареног резултата на једној фудбалској утакмици, на Светском првенству у Јужноафричкој Републици у фудбалу 2010. године. Тактичком анализом обухваћено је укупно 60 утакмица. Екипе су распоређене у 3 групе на основу оствареног резултата на утакмицама. Први субузорак испитаника (победа) чиниле су екипе које су победиле у коначном резултату, други субузорак (нерешено) биле су екипе које су играле нерешено (без победника), док су трећи субузорак (пораз) чиниле екипе које су поражене у регуларних 90 минута игре. На основу претходно обрађених података, који су добијени софтверским пакетом „AMISCO“ и званичног сајта светске фудбалске федерације (www.fifa.com), посматрани параметри везани су за ефикасност игре, нападачко средство тактике - додавање лопте и структуру додавања лопте. На основу анализе фреквенције успешних напада запажено је да постоји статистички значајна разлика у броју успешних напада између екипа које су оствариле различите резултате

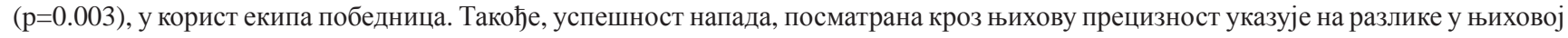
расподели ( $=0.000)$ између поменутих група. Резултати такође указују да укупна претрчана дистанца, на нивоу једног тима, није повезана са коначним резултатом. Међутим, посед лопте ( $\mathrm{p}=0.001)$, укупан број додавања ( $=0.015)$ и укупно број тачних

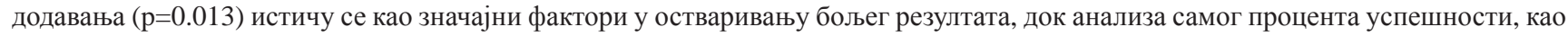
и структуре игре која примењује додавање, односно дужине додавања, није или је веома мало повезана са коначним резултатом. Резултати ове студије могу помоћи у идентификацији оних средстава тактике напада, у фудбалу, који доприносе постизању бољих резутата.
\end{abstract}

Кључне речи: ФУДБАЛ / АНАЛИЗА ИГРЕ / ТАКТИКА / РЕЗУЛТАТ / ДОДАВАњЕ ЛОПТЕ

\section{УВОД}

Тактика у фудбалу представља важан фактор у припреми екипе или појединца за такмичење. Недостатак тактичке припреме и развоја стратегије један је од основних разлога за лоше наступе и резултате једне екире (Ali, 1998). Тактика напада је део укупне стратегије и има веома важну улогу на фудбалској утакмици. Велики број истраживања је усмерен на анализу офанзив-

Коресподенција са: Бојан Леонтијевић, Факултет спорта и физичког васпитања, Београд, Благоја Паровића 156, e-mail: bojan.leontijevic@dif.bg.ac.rs 
них акција у игри, јер је постизање гола основни циљ игре. Голови и ударци на гол су кључни елементи који одређују успех или неуспех фудбалске екипе.

Статистичка анализа игре, с обзиром на појединачне, групне и тимске техничко-тактичке елементе, свакако је начин који се може користити за описивање и праћење тактичких испољавања и резултата на такмичењу. Међутим, детаљније анализе утакмица су објективнији начин сагледавања тактичких активности у току утакмица (Carling et all., 2005).

Ефикасан начин идентификације основних елемента постизања успешног резултата је да се утврди квалитет и квантитет техничких и тактичких радњи од стране играча победничког и пораженог тима у директној конкуренцији (Szwarc, 2004). Индикатори извођења су дефинисани као избор и повезаност праћених параметара који дефинишу поједине аспекте извођења и на основу којих се постиже бољи усрех. Упркос ограничењима која могу настати, при доношењу закључака, изведеним на основу оваквих студија, овај тип података је користан у циљу праћења и предвиђања развоја фудбалске игре на плану тактике.

У досадашњим истраживањима, везаним за анализу фудбалских утакмица, углавном су истраживачи били фокусирани на анализу постигнутих голова и активности које су доводиле до ударца на гол (успешних напада) на најквалитетнијим репрезентативним такмичењима - светска и континентална првенства (Јанковић и сар., 2009; Szwarc, 2008; Јанковић и Леонтијевић , 2007; Acar et all., 2007; Luhtanen et all., 2001), а затим и на најквалитетнијим клупским такмичењима: (Buraczewski \& Cicirko, 2007; Szwarc, 2007; Bergier \& Buraczewski, 2007). Један број студија покушао је да пронађе узрочно-последичну везу између појединих статистичких показатеља и оствареног резултата (Lago et all., 2010, Rampinini at all., 2009, Armatas at all., 2009), док су поједини аутори покушали да пронађу разлике између успешних и неуспешних екипа на различитим репрезентативним, клупским и националним такмичењима приликом организације успешних напада, као и у структури и ефикасности додавања (Hughes \& Franks, 2005; Jones et all., 2004; Szwarc, 2004; Hook \& Hughes, 2001; Grant et all., 1999; Hughes et all., 1988). Један број радова анализирао је структуру и ефикасност техничког испољавања фудбалера на најквалитетнијим фудбалским такмичењима (Јанковић и Леонтијевић, 2008, 2009; Rampinini et all., 2009).

Резултати наведених истраживања указују на разлике у карактеристикама игре екипа које постижу различите резултате. Разлике у игри огледају се, пре свега у већој ефикасности приликом удараца на гол, као и у примени додавања лопте екипа које остварују боље резултате. Међутим, мали број анализа обухватио је оба, претходно наведена параметра, запажа се и незнатан број радова који је детаљније истраживао успешност и структуру додавања, као директне индикаторе остваривања позитивног или негативног резултата. Светско првенство у Јужноафричкој републици (СП ЈАР), као репрезент савременог врхунског фудбала, може да донесе прецизнији одговор на, до сада, још непознате релације између тактике и резултата у фудбалу.

Дакле, услед малог броја истраживања везаних за тактичко испољавање фудбалских екипа, различитог нивоа успешности, дефинисаног на основу коначног резултата појавила се потреба за оваквим видом истраживања. Потребно је утврдити да ли и у којој мери постоје разлике у примени појединих нападачких средстава између екипа које су оствариле различит резултат на крају фудбалске утакмице, односно може се рећи да ли су биле успешне или неуспешне. Такође, мали број истраживања, која се баве овом проблематиком, су успела да идентификују техничко-тактичке аспекте игре и потом пронађу њихову везу са резултатом.

Предмет овог истраживања је откривање и праћење законитости у нападу за остваривање што бољег резултата у фудбалској игри. Предметом рада обухваћено је просторно тактичко испољавање фудбалских тимова, кроз анализу структуре оних нападачких акција које су завршене ударцем на гол противника, као и сама структура додавања. Под тактичким испољавањем у нападу, првенствено се подразумевају техничкотактичке активности које појединац, група играча или читава екипа предузима, како би у односу на део терена, тактичким средствима, од противника предузела рационалне и ефикасне акције у циљу постизања гола.

Циљ рада је упоређивање тактичког испољавања у нападачким активностима фудбалских 
екипа, различитог нивоа успешности, дефинисаног на основу оствареног резултата на фудбалској утакмици у регуларних 90 минута, без продужетака, на Светском фудбалском првенству, одржаном у Јужноафричкој Републици 2010. године. Прецизније, потребно је утврдити да ли и у којој мери постоје разлике у примени појединих тактичких средстава, у организацији успешних напада, и да се утврди да ли је статистички дозвољена подела на победничке, поражене и екипе које су оствариле нерешен резултат на Светском првенству.

\section{МЕТОД РАДА}

\section{Узорак испитаника}

У овом истраживању анализирано је 60 утакмица светског првенства одржаног у Јужноафричкој Републици 2010. године, односно анализиране су утакмице које су трајале 90 минута, без продужетака. Екипе су подељене у 3 групе субузорака на основу постигнутог резлтата на крају утакмице. Прву групу субузорака (победа) чиниле су екипе које су победиле у коначном резултату, други субузорак испитаника (нерешено) чиниле су екипе које су играле нерешено (без победника), док су трећи субузорак (пораз) чиниле екипе које су биле поражене у регуларних 90 минута игре.

\section{Процедуре}

У анализи, претходно обрађених, укупно 60 утакмица Светског фудбалског првенства у Јужноафричкој Републици 2010. године, посматрани су параметри који су добијени софтверским пакетом „AMISCO“ (софтверски пакет који се користи приликом анализе структуре игре у ФИФА и УЕФА такмичењима) и преузети са званичног сајта светске фудбалске федерације (www. fifa.com), везани за ефикасност игре, игру са применом додавања, као и структуру додавања. За потребе рада обрађени су подаци који директно утичу на коначан резултат једне фудбалске утакмице, нападачке активности екипа учесница, а то су ударци на гол и додавања репрезентација учесница XIX светског првенства.

\section{Варијабле}

У овом раду истраживачка пажња усмерена је на праћење успешно организованих напада који су завршени тактичким средством ударац на гол, као и карактеристике игре са применом додавања, као нападачког средства тактике, поседа лопте и саме структуре (дужине) додавања.

Укупан број успешних напада на једној утакмици представља прву варијаблу којом се објашњава повезаност резултата и техничкотактичке успешности екипа. Друга варијабла је дефинисана као ефикасност успешних напада анализирана кроз прецизност ударца на гол противника, где се разликују прецизни напади (ударци у оквир гола), непрецизни напади (ударци ван оквира гола) и ефикасни напади (голови). Док трећу варијаблу представља додавање, односно обим и ефикасност игре са применом додавања у току утакмице (посед лопте, укупан број додавања - означена варијабла у табелама УБП, број тачних додавања - означена варијабла у табелама УБУП, проценат тачних додавања - означена варијабла у табелама УПАС, као и карактеристике саме игре са применом додавања - кратких, средњих и дугих додавања).

\section{Статистичка обрада података}

Стандардна дескриптивна статистичка анализа (укупна и средња вредност, као и стандардна девијација) је рачуната за сваку варијаблу. Из простора компаративне статистике коришћена је непараметријска анализа варијансе, Kruskal Wallis тест, којим су утврђене разлике између средњих вредности фреквенција код појединих варијабли, као и Man-Vitni тест којим су прецизније објашњене евентуалне разлике. Chi-square тест употребљен је за откривање повезаности између резултата екипа и расподеле променљивих у оквиру посматраних параметара. Ниво статистичке значајности био је на $p<0.05$. Сви статистички тестови су били обрађени коришћењем SPSS 17.0 програма (SPSS INC, Chicago, IL). 


\section{РЕЗУЛТАТИ И ДИСКУСИЈА}

Посматрајући чињеницу да је резулатат у фудбалу детерминисан великим бројем факто$\mathrm{pa}$, једна група аутора сматра да се овакав приступ у анализи ефикасности игре, мора узети са резервом (Lago, 2009; Taylor et al., 2008). Међутим, ово посматрање може указати на одређене законитости које се могу искористити у анализи структуре фудбалске игре, и што је веома важно, резултати добијени овом студијом могу имати директну практичну импликацију, како у тренажној технологији, тако и у директној припреми за такмичење.

На XIX светском фудбалском првенству у Јужноафричкој Републици, учествовале су 32 репрезентације које су у првој фази биле подељене у 8 група. У групној фази одиграно је 48 утакмица, од којих су 34 завршене победом једне репрезентације, док је 14 утакмица завршено без победника. У елиминационој фази одиграно је 16 утакмица, од којих су на 4 утакмице играни продужеци и оне нису ушле у анализу, због валидности добијених резултата. Овим радом дошло се до података који указују на повезаност резултата, и тактичког испољавања екипа чије су карактеристике игре анализиране.

Табела 1. Упоредна анализа просечног броја успешних напада екипа по утакмици на СП 2010 у зависности од оствареног резултата.

\begin{tabular}{|c|c|c|c|}
\hline Успешни напади & победа & нерешено & пораз \\
\hline Процечно & 16.02 & 12.07 & 12.72 \\
\hline $\begin{array}{l}\text { Стандардана } \\
\text { девијација }\end{array}$ & 5.46 & 5.36 & 4.68 \\
\hline Значајност (р) & & $0.003^{*}$ & \\
\hline Средишњи ранг & 74.25 & 49.82 & 53.25 \\
\hline Хи квадрат & & 11.872 & \\
\hline
\end{tabular}

На основу броја успешних напада у току утакмице (они напади који су завршени ударцем на гол противника) и поредећи њихове фреквенције, уочава се значајно већи број оваквих напада код екипа које су оствариле бољи резултат, односно биле боље пласиране $(\mathrm{p}=0.003)$ (Табела 1$)$. Овај податак, иако прилично очекиван, указује да тимови који постижу боље резултате преузимају иницијативу и побеђују тако што имају бољу организацију напада од противника. Већи број удараца на гол, обезбеђује и већу вероватноћу за постизање гола, али указује на одређени однос на терену између два противника. Шварц (Szwarc, 2004) анализом Светског првенства 2002. године, добија сличне резултате према којима су финалисти упутили просечно 18 удараца на гол, што је више у односу на екипе које нису дошле до завршнице такмичења (просечно 14.08 удараца). Грант и сарадници (Grant et al., 1999) дошли су до података, анализирајући Светско првенство 1998. године, да успешне екипе просечно остваре 18.1 удараца на гол, док неуспешне екипе остваре готово дупло мање удараца 9.5. Такође, Хјуз и Френкс (Hughes, \& Franks, 2005) су упоредили успешност тактичких активности између успешних и неуспешних тимова на Светском првенству 1990. године и такође дошли до резултата према којима успешније екипе остварују и већи број удараца на гол од неуспешних екипа. Роксбург (Roxburg, 2008), изнео је податке да су на Европском првенству 2008. године тимови полуфиналисти извели просечно 15 успешних напада по утакмици, док су четири последњепласиране екипе у групи оствариле просечно 13,2 успешна напада. У сезони 2009/10. у Лиги шампиона екипе које су се пласирале у четвртину финала имале су просечно 13.13 успешних напада, а осам последње пласираних екипа у групи 8.76 таквих напада, док у Лиги Европе, другом по квалитету Европском клупском такмичењу, екипе четвртфиналисти имале су просечно 11.99 успешних напада, а осам последње пласираних екипа у групној фази такмичења просечно 9.38 напада. (www.uefa.com). На основу анализе шпанске професионалне лиге (актуелни светски првак), резултати екипа победница бележи просечно 14.4 ударца на гол, екипе које су играле нерешено 13.6, а поражене екипе просечно 12 удараца на гол, указују подаци Лага и сарадника (Lago, et al., 2010). Слични резултати добијени су анализом грчког фудбалског првенства (Armatas et all., 2009), као и италијанске „Серие A“ (Rampinini et all., 2009). Јанковић и сарадници (2009) анализирајући број успешних напада четири првопласиране екипе на три претходна светска првенства $(1998,2002,2006)$, дошли су до резултата да је просечан број успешних напада на XVI светском првенству био 17.68, на XVII светском првенству 11.46, док је на XVIII свет- 
ском првенству 10.96 напада. Претходно наведени резултати недвосмислено указују да је потребно знатно више пажње посветити анализи игре, а у оквиру те анализе, тактици напада, односно методици ефикасне организације напада.

Као наставак анализе тактике напада, поред учесталости успешних нападачких акција, изузетно је битна прецизност завршних удараца на гол. Сви ударци који се упућују на гол противника, према опште прихваћеној класификацији, деле се на прецизне и непрецизне, док се постигнути голови дефинишу као ефикасни ударци. У односу на овај усвојени показатељ, резултати студије показују да постоје значајне разлике $(\mathrm{p}=0.000)$ у расподели удараца различите пре- цизности код екипа које су оствариле различите резултате (графикон 1). Јанковић и сарадници (2009) анализирајући прецизност успешних напада четири првопласиране екипе на три светска првенства (1998, 2002, 2006), дошли су до података да је просечан број непрецизних нарада на XVI светском првенству био 10.61, на XVII светском првенству 6, док је на XVIII светском првенству 5.36 напада, док је прецизних напада на XVI светском првенству било 5.21, на XVII светском првенству 3.68, док је на XVIII светском првенству 4.14 напада, а ефикасних напада на XVI светском првенству било је 1.86, на XVII светском првенству 1.79, а на XVIII светском првенству 1.5. Ови подаци недвосмислено указују на то да се укупан број успешних напада смањује.

Графикон 1 Анализа прецизности успешних напада и њихова расподела у зависности од оствареног резултата на СП 2010. изражена кроз просечне вредности на једној утакмици

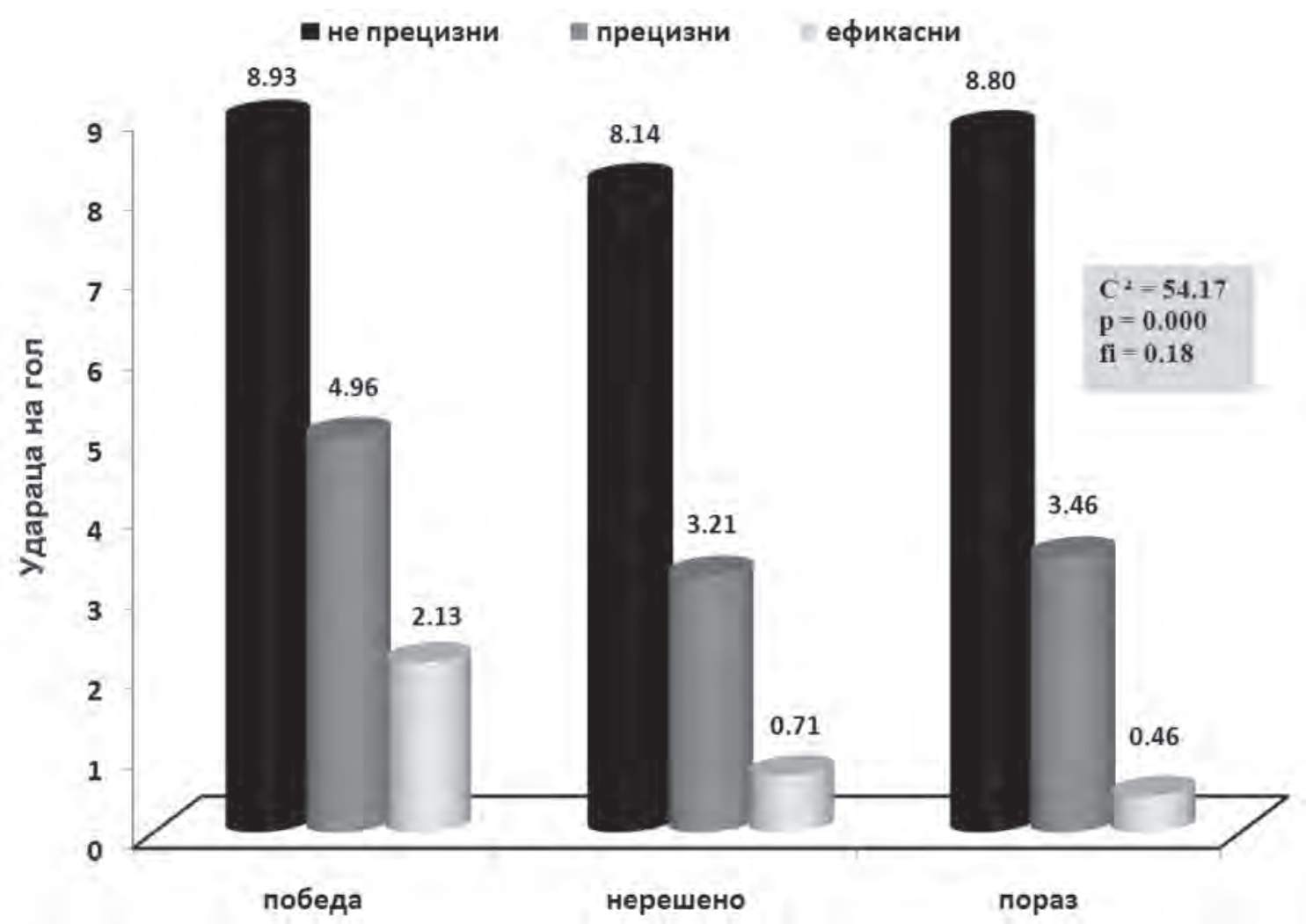

На основу резултата анализе може се констатовати да екипе победнице остварују процентуално већи број ефикасних напада у односу на мање усрешне тимове. Такође може се истаћи и да све три групе субузорака процентуално имају подједнак број прецизних удараца, док поражене и екипе које су играле нерешено имају дале- ко већи проценат непрецизних удараца (графикон 1). Ове разлике у расподели удараца различите прецизности могу се објаснити квалитетнијим појединцима који реализују нападе код победничких екипа, али и раздаљином са које се упућују завршни ударци. 
Лаго и сарадници (Lago et al., 2010) закључују да победничке екипе упућују више удараца на гол од поражених и екипа које су играле нерешено у оквиру шпанске професионалне лиге. Такође, победничке екипе имају већу ефикасност него екипе које су поражене и које су своје утакмице завршавале нерешеним резултатима (46.17 $\%, 37.545$ и $35.57 \%$, просечно). У групи екипа победница однос голова и удараца био је 1:7.5 (на сваких седам удараца постиже се по један гол), у групи нерешених је 1:17, док је у групи поражених екипа овај однос 1:27.65. Из овога се види да успешније екипе имају већи проценат ефикасности (реализације) од осталих екипа. Роксбург (Roxburg, 2008) анализирајући Европско првенство 2008. године, дошао је до података да су екипе полуфиналисти имале однос 1:9, док су четири последње пласиране екипе у групи имале 1:28, док су Хук и Хјуз (Hook, \& Hughes, 2001), изнели да је на Европском првенству 2000. године, однос успешних екипа био је 1:7, а неуспешних 1:17. Шварц (Szwarc, 2007) је анализирајући финала Лиге шампиона дошао до односа од 1:8 екипа које су освојиле лигу шампиона и 1:24 поражених екипа. Ови подаци нам указују да успешнији тимови боље реализују указане прилике за гол и имају већи проценат реализације, што је такође један од предуслова доброг резултата. Анализирајући тимове италијанске „Серие А“ постоје значајне разлике између пет првопласираних тимова са једне, и пет последњепласираних са друге стране, у погледу прецизних удараца, у корист боље пласираних екипа (Rampinini et all., 2009). Такође, Арматас и сарадници (Armatas, et al., 2009) закључују да код боље пласираних екипа однос голова и ударца на гол је 1:7.8, док код две последњепласиране екипе тај однос је 1:14.2.

Из овог, као и из претходних истраживања може се закључити да је разлика између победничких и поражених тимова углавном евидентна у ударцима на гол, као и ефикасности тих удараца на гол (Grant et all., 1999). Посматрано кроз појединачне примере, често се догађа да екипа која упути мање удараца на гол од противника оствари победу, међутим посебна вредност овог истраживања огледа се у великом броју анализираних утакмица, 94\% свих одиграних утакмица на светском првенству, тако да добијени резулати пружају поуздане показатеље тактичке ефикасности екипа учесница. Резултати овог истраживања свакако указују да екипе које су оствариле победе организују ефикасније своје нападе, којима долазе у изгледније ситуације за постизање гола али и располажу са квалитетнијим нападачима у односу на поражене и тимове који су своје утакмице завршавали нерешеним резултатом. Међутим, репрезентације Италије, победник Светског првенства 2006. године, у односу на седам екипа са којима је играла, није се разликовала у укупном броју удараца на гол, као ни у расподели удараца различите прецизности (Acar et all., 2007).

Физичка припремљеност у савременом фудбалу један је од веома битних параметара који могу да утичу на исход фудбалске утакмице. На основу резултата ове анализе види се да не постоји значајна разлика између три групе екипа учесница СП у односу на укупну пређену дистанцу на нивоу целе екипе (табела 2), где су све екипе приближно у просеку претрчале 105 км на једној утакмици, или око 10500 м по играчу. Овај податак говори да није само довољно бити физички припремљенији од противника, већ је потребно адекватним тактичким планом мењати ритам и динамику игре како би се противник изненадио. Недостатак добијених података може бити у томе што се не зна у којим зонама интензитета су биле ове кретне активности и колико су играчи који играју на различитим позицијама претрчали. Као и то, што је изузетно важно за разумевање тактике фудбалске игре, како се однос претрчаних километара мењао у зависности од резултата, па чак и од тренутног поседа лопте и појединих ситуација у игри. 
Табела 2 Упоредна анализа структуре и успешности игре са додавањима, и пређене дистанце (на нивоу целе екире) на СП 2010 између екипа које су оствариле различите резултате, изражена кроз просечне вредности на једној утакмици

\begin{tabular}{cccccccc}
\hline & \multicolumn{2}{c}{ ПОБЕДА } & \multicolumn{2}{c}{ НЕРЕШЕНО } & \multicolumn{2}{c}{ ПОРАЗ } & \multirow{2}{*}{ р(вредност) } \\
\cline { 2 - 6 } & Average & stdev & Average & stdev & Average & stdev & \\
\hline УКМ & 105.2 & 6.3 & 105.8 & 5.1 & 103.6 & 5.7 & 0.200 \\
\%ПЛ & $52.3^{*}$ & 6.0 & 50 & 5.3 & 47.6 & 6.0 & 0.001 \\
УБП & $533.5^{* *}$ & 114.7 & 480.8 & 95.8 & 473 & 94.4 & 0.015 \\
УБУП & $391.6^{*}$ & 115.3 & 342.1 & 99.1 & 331.9 & 88.5 & 0.013 \\
\%УПАС & 72.3 & 7.1 & 69.9 & 7.5 & 69.2 & 6.9 & 0.108 \\
\hline
\end{tabular}

УКМ - укурно пређених километара екипно; \% ПЛ - процентуална вредност у односу на посед лопте; УБП укупан број додавања на утакмици; УБУП - укупан број успешних додавања на утакмици; \% УПАС - проценат успешности додавања; * значајно више од поражених екипа; ** значајно више и од поражених и од екипа које су играле нерешено; За р < 0.05 (Kruskal -Volisov тест)

Позитивни посед лопте у фудбалу је жељена опција, али без правог техничког квалитета овај приступ повећава ризик од контранапада, а понекад доводи до прекомбиновања и недостатка завршнице (Roxburg, 2008). Анализирајући податке, који се односе на посед лопте, из табеле 2 уочава се да екипе победнице остварују значајније већи посед лопте од екипа које су поражене $(\mathrm{p}=0.001)$. Овакав податак значи да екипе које успевају да контролишу игру, путем значајније већег поседа лопте од противника, остварују и боље резултате. Поредећи успешност тактичких активности између успешних и неуспешних тимова на Светском првенству 1990. године, Хјуз и Френкс (Hughes, \& Franks, 2005) су пронашли разлике између ове две групе екипа, где су успешнији тимови имали боље показатеље у односу на посед лопте. Такође, Хук и Хјуз (Hook, \& Hughes 2001) су утврдили да успешни тимови имају бољи посед од неуспешних тимова на Европском првенству 2000. године. Аутори су предложили да чување лопте дуже у поседу је индикативно за успех. Џефет и Хјуз (Japheth, \& Hughes, 2001) анализирајући тактичке активности репрезентације Француске, која је у том тренутку била светски и европски првак, изнели су да је Француска у стању да створи знатно више удараца, а такође има способност да задржи лопту у свом поседу дуже време у односу на противничке екипе. Џонс и сарадници (Jones, et al., 2004) анализирајући енглеску „Премијер лигу“ дошли су до података да успешне екипе имају већи посед лопте од неуспешних. Сви претходно наведени резултати недвосмислено указују да је за постизање бољих резултата потребно имати лопту у поседу дуже од противника и тако наметнути свој стил игре, међутим Лаго (Lago, 2007), анализирајући шпанску професионалну лигу „Примеру“, долази до података према којима поражене екипе имају значајно већи посед лопте од екипа које су играле нерешено или су победиле. У прилог овим резултатима иду, свакако и актуелна дешавања и резултати, како на клупском тако и на репрезентативном нивоу, која указују на доминацију екипа које гаје нападачку игру, односно имају дужи посед лопте од противника. Прави репрезенти оваквог начина игре су, свакако, FC „Barselona“ као и шпанска репрезентација, актуелни прваци Европе и света. По доминацији на тактичком плану и техничким активностима са лоптом, одређени број селекција, а посебно Шпанија, Холандија и Немачка, наметнуле су на СП игру противницима и са упечатљивим наступима искористили предности поседа лопте.

Узимајући у обзир чињеницу да је примопредаја лопте основна јединица сарадње два играча у пољу, и да ће од њене ефикасности зависити и ефикасност тактике напада једног тима, однос укупног броја додавања и укупног броја тачних додавања представља битан показатељ ефикасности игре у пољу једног тима. У савременом фудбалу, потребни су фудбалери који имају висок проценат тачних додавања, посебно у маневарском простору и то под притиском противничких игра- 
ча. Узимајући у обзир игру у тесној маркацији, на сваком делу терена, до изражаја долази пре свега техничка обученост играча, и способност да лопту контролишу у најсложенијим ситуацијама игре (Јанковић и сар., 2009). Посматрајући укупан број додавања екипа учесница Светског првенства 2010. године, може се видети да има значајних разлика $(p=0.015)$ у просечном броју додавања у току утакмице. Из анализе се запажа да победничке екипе имају значајно више додавања и од поражених екипа, као и од екипа које су играле нерешено (табела 2). Овакав резултат надовезује се на постојање разлика у времену поседа лопте, али значајно више додавања победничких екипа у односу на остале две групе говори да екипе победнице играју и једноставније, брже са краћим задржавањем лорте у поседу од стране играча. Анализирајући сезону 2009/10. Лиге шампиона у елиминационој фази такмичења, просек укупног броја додавања био је 459.2 (www.uefa.com), док су финалисти овог такмичења просечно остваривали 478 додавања, а њихови противници, током такмичења, 305.5 (Szwarc, 2007). Однос броја додавања у финалној утакмици, претходно наведеног такмичења, био је 716 - FC „Barselona“ као победник и 307 - FC „Arsenal“ као поражени у овој утакмици (Zubillaga et all., 2007). Шварц (Szwarc, 2004) је изнео анализу броја додавања екипа финалиста XVII светског првенства 2002. године и њихових противника у међусобним дуелима, где су финалисти просечно остваривали 355.16 покушаја додавања, а противници просечно 387.58 додавања.

Када је број тачних додавања у питању уочава се такође, већи број успешних додавања код екипа које остварују боље резултате (табела 2). Такође, овде постоји значајна разлика између екипа победница и екипа које су изгубиле на крају меча $(\mathrm{p}=0.013)$. У сезони 2009/10 Лиге шампиона у елиминационој фази такмичења просек успешног броја додавања био је 328.1 (www. uefa.com). На Европском првенству 2008. године успешне екипе, тј. оне које су прошле у другу фазу такмичења имале су просечно 359.9 успешних додавања, док екипе које нису прошле у елиминациону фазу такмичења имале су просечно 217.4 успешна додавања (www.uefa.com). Екипе освајачи Лиге шампиона имале су просечно 362.14 додавања, док су њихови противници остварили 234.43 додавања (Szwarc, 2007). Грант и сарадници (Grant, et al., 1999) изнели су податке према којима успешне екипе остваре 362.7 просечно тачних додавања, а неуспешне 308.9 на Светском првенству 1998. године. Екипе финалисти XVII светског првенства 2002. године имале су просечно 292.75 додавања, док су њихови противници остварили 314.67 додавања (Szwarc, 2004). Поредећи резултате ове анализе са подацима претходних истраживања, може се закључити да је на последњем светском првенству забележен највећи број тачних додавања од стране екипа победница и то просечно 391.6 (табела 2).

Када је проценат тачних додавања, односно ефикасност игре са применом додавања у питању, види се да не постоји статистички значајна разлика између екипа у односу на коначан резултат $(\mathrm{p}=0.108)$ (Табела 3). На основу ових резултата, закључак је да, екипе које претендују на висок пласман, морају пре свега да располажу са квалитетним појединцима, односно да посвећују више пажње, у тренажном процесу, техничко-тактичком обучавању својих играча, јер ефикасност њихове игре директно утиче на остварени резултат тима. У сезони 2009/10. Лиге шампиона у елиминационој фази такмичења проценат успешности додавања био је 70\% (www.uefa.com). На Еврорском првенству 2008. године успешне екипе, тј. оне које су прошле у другу фазу такмичења имале су проценат успешности $75.6 \%$, док екипе које нису прошле у елиминациону фазу такмичења имале су проценат од 72.4\%. (www.uefa.com). Међутим, Зубилага и сарадници (Zubillaga, et al., 2007), анализирајући финале Лиге шампиона дошли су до резултата да је екипа FC „Arsenala“, која је водила голом предности у првом полувремену, имала проценат успешности 78\%, а Барселона 85\%, док у другом полувремену када је екипа Барселоне преокренула резултат и славила у том мечу, у других 45 минута имала проценат успешности 89\%, а екипа Арсенала само $62 \%$.

Анализирајући структуру игре са применом додавања, у зависности од дужине додавања, и њен утицај на остварени резултат, уочава се да не постоји статистички значајна разлика у успешности додавања, различите дужине, између екипа које су оствариле различит резултат (графикон 2). Процентуално посматрајући, екипе највише се примењују додавања средње дужине (63\%), затим кратка додавања (24\%) и најмање дуга додавања (13\%). У односу на примену ових 
врста додавања, нема разлике у њиховој расподели код ове три групе екипа, дакле екипе независно од оствареног резултата користе у подједнакој мери кратка, средња и дуга додавања. Сколдинг и сарадници (Scoulding, et. al., 2004) анализирајући додавања на СП 2002, дошли су такође до података да не постоје значајне разлике у дужини додавања између успешних и неуспешних екипа.
Међутим, Рампинини и сарадници (Rampinini, et al., 2009) анализирајући успешност у италијанској професионалној лиги „Серији А“, дошли су до података да се значајно разликују успешне екипе у укупном броју кратких додавања и успешним кратким додавањима у односу на неуспешне екипе.

Графикон 2. Проценат успешности кратких, средњих и дугих додавања у зависности од оствареног резултата.

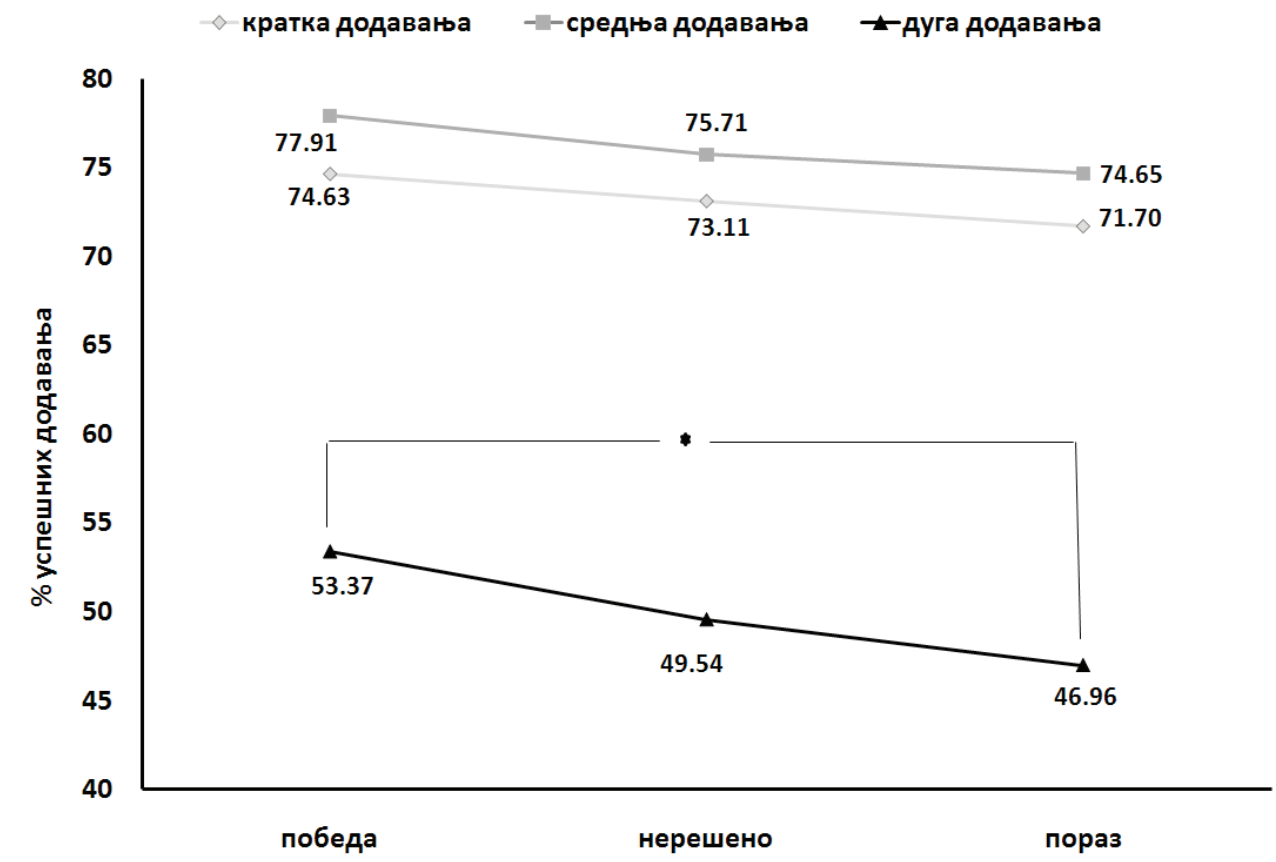

* зачајно већи проценат тачних, дугих додавања екипа победница у односу на поражене екипе

Када је ефикасност додавања, различите дужине у питању, из графикона 2 уочава се да екипе имају приближно једнаку успешност приликом реализације кратких и средњих додавања, где се ефикасност средњих додавања креће од 74\% - 78\%, а ефикасност кратких додавања од 71\% $75 \%$, уз неочекиван закључак да су репрезентације биле прецизније приликом средњих додавања у односу на додавања на краћим растојањима. Међутим, из графикона 2 се види да су екипе победнице, приликом реализације дугих додавања, имале значајно већи проценат успешних, дугих додавања у односу на поражене екипе. Из оваквих резултата се не може са сигурношћу тврдити да су екипе побеђивале захваљујући прецизнијим дугим додавањима, али свакако то може бити важан елемент тактике фудбалске игре, где се пре- носним лоптама веома лако мења „тежиште игре“ и користи спорије померање противника у одбрани. Прецизно дуго додавање посебну вредност има и приликом центаршута са крилних позиција али и ситуација прекида игре, путем којих, према најновијим истраживањима, се постиже и преко $50 \%$ свих голова.

Иако оваква истраживања испитују индикаторе успеха у фудбалу, нека ограничења или методолошки проблеми у проучавању студија могу се посматрати. Многе од ових студија нису успеле да покажу поузданост за прикупљање података система који се користи (Hook \& Hughes, 2001). Поред тога, резултате би требало узети са опрезом, јер резултати су добијени кроз анализу на ограниченом броју екипа, репрезентативни ниво, и као такви не могу да важе за остала такмичења. 
Потребно је у даљим радовима, упоредити ефикасност игре екипа репрезентативног и клупског нивоа, и наравно све то у односу на постигнути резултат. Континуитет праћења утицаја појединих тактичких опредељења обезбедиће идентификацију рационалних и ефикасних тактичких варијанти.

\section{ЗАКЉУЧАК}

Техничко-тактичке активности, су изузетно важан сегмент структуре фудбалске игре, знајући да је у савременом, врхунском фудбалу једино мерило вредности резултат, онда је квантификовање свих активности појединца, групе играча или целог тима које су допринеле постизању врхуског спортског резултата суштинска ствар у програмирању и управљању тренажним процесом једног тима.

Разлике између победничких и поражених тимова су углавном евидентне у учесталости и ефикасности удараца на гол, као и успешности додавања (Grant et all., 1999). Резултати ове анализе, у великој мери потврђују резултате претходних студија, али и указују на расподелу променљивих код појединих, посматраних параметара, и откривају њихову везу на основу оствареног резултата.

- Анализирајући повезаност тактичког испољавања и оствареног резултата, на основу праћења утакмица Светског првенства у Јужноафричкој Републици 2010. године, могу се изнети следећи закључци:На основу броја успешних напада (удараца на гол), потврђено je да постоји статистички значајна разлика у просечном броју успешних напада између екипа које су оствариле различите резултате, и та разлика је у корист екипа које су победиле.

- Резултати анализе успешних напада и њихова подела на прецизне, непрецизне и ефикасне нападе, указују да од броја изведених напада зависи коначни исход на великом такмичењу, као што је Светско првенство у Јужноафричкој Републици 2010. године.

- Укупно претрчана дистанца по субузорцима није повезана са коначним резултатом, јер нема статитистички значајне разлике при постизању коначног резултата.
- На основу поседа лопте потврђено је да постоји статистички значајна разлика у проценту поседа између екипа које су оствариле различите резултате, и та разлика је у корист екипа које су победиле.

- Екипе које су победиле, такође значајно се разликују у односу на остале две групе у укупном броју додавања, као и броју успешних додавања оствареним на Светском првенству у Јужноафричкој Републици 2010. године.

- Међутим, анализирајући проценат тачних додавања, запажа се да не постоји статистички значајна разлика између екипа на основу оствареног резултата.

- Анализирајући структуру додавања, односно тактичко опредељење тренера, види се да не постоји значајна разлика у примени додавања различите дужине између три анализиране групе, али када је ефикасност додавања различите дужине у питању, екипе победнице су знатно успешније у дугим додавањима, док је успешност кратких и средњих додавања приближно једнака.

У раду су представљене вредности које се могу користити као нормативни подаци за пројектовање и процену такмичарске активности фудбалских екипа, врхунских перформанси на колективан начин. Међутим, резулатати до којих се дошло овом анализом су специфични и одсликавају дешавања у датом тренутку, са свим специфичностима такмичења, важности утакмица, репрезентативнних екипа и као такви се не могу генерализовати и на основу њих не би требало доносити закључке о тактици фудбалске игре на глобалном нивоу.

Будуће анализе, којима ће ова студија послужити као теоријски оквир, требало би да пронађу односе у тактици игре, било у нападу или у одбрани, између најуспешнијих тимова на репрезентативним континенталним такмичењима, односно међународним клупским или националним шампионатима, који на директан или индиректан начин утичу на резултат у фудбалу.

\section{Практична примена}

Вредности података о анализи игре, без обзира да ли су или нису значајне, могу да послуже као повратна информација тренерима приликом планирања и програмирања тренажних ак- 
тивности, али не и као једини извор информација о такмичарској успешности појединаца или тима. Примена резултата, добијених оваквим анализама, огледа се пре свега у теоријском смислу, где се на основу ових резултата могу прецизније уочити одређене тенденције развоја тактике фудбала, али и предвидети правац даљег развоја одређених

\section{ЛИТЕРАТУРА}

1. Acar, M., Yapıcıoglu B., Arıkan, N., Yalcın, S., Ates, N. \& Ergun M. (2007). Analysis of goals scored in 2006 World Cup. In Reilly and Korkusuz. Proceedings from: Science and football VI: Sixth World Congress on Science and Football (pp. 235-242). Oxon: Routledge.

2. Ali, A. (1988). A statistical analysis of tactical movement patterns in soccer. In T. Reilly, A. Lees, K. Davids, W.J. Murphy, (Eds) Science and Football, (pp. 302-308). London: E. \& F. Spon.

3. Armatas, V., Yannakos, A., Zaggelidis, G., Skoufas, D., Papadopoulou, S. \& Fragkos, N. (2009). Differences in offensive actions between top and last team in Greek first soccer divison. A retrospective study 1998-2008. Journal of Physical Education and Sport, 23(2), 1-5.

4. Armatas, V., Yiannakos, A., Papadopoulou, S. \& Skoufas, D. (2009). Evaluation of the goals scored in top ranking soccer matches: Greek "Superleague" 2006-07. Serbian Journal of Sports Sciences, 3(1), 39-43.

5. Buraczewski, T. \& Cicirko, L. (2007). Chosen elements of actions resulting in goals in football matches of the highest rank. Moloda Sportivna Nauka Ukraine, 3, 67-71.

6. Bergier, J. \& Buraczewski, T., (2007). Analysis of successful scoring situations in football matches. Journal of sports science \& medicine, 6(10), 199-209.

7. Grant, A.G, Williams, A.M, \& Reilly, T. (1998). An analysis of the successful and unsuccessful teams in the 1998 World Cup. Insight The F.A. Coaches Association Journal, 2, 21-24. тактичких аспеката и у офанзиви и у дефанзиви. Такође, са аспекта праксе и технолошког процеca, информације добијене оваквим студијама вишеструко су корисне у идентификацији ефикасних средстава тактике фудбала, али и примене појединих елемената технике, који доприносе остваривању врхунских резултата у фудбалу.

8. Zubillaga, A., Gorospe ,G. Mendo, A. H. \& Villasenor, A.B. (2007). Match analysis of 2005-06 Champions League Final with Amisco system, (abstract). Journal of sports science \& medicine, 6(10), 20.

9. Јанковић, и А., Леонтијевић, Б. (2007). Упоредна анализа у брзини извођења брзих напада у фудбалу (на примеру Европских и Латиноамеричких репрезентација). У Ненад Живановић (ур.). ФИС Комуникащије (97107), Ниш: ФФК.

10. Јанковић, А. и Леонтијевић, Б. (2008). Структура техничко такмичарске активности у савременом фудбалу. Физичка култура, 62 (12), 159-169.

11. Јанковић, А. и Леонтијевић, Б. (2009). Анализа примене појединих техничких елемената у фудбалу у зависности од позиције играча у тиму. Физичка култура, 63(1), 76-88.

12. Јанковић, А., Леонтијевић, Б. и Мићовић, Б. (2009). Тенденције развоја тактике игре кроз анализу успешних напада на XVI, XVII и XVIII Светском првенству у фудбалу. У В. Копривица, и И. Јухас (ур.) Зборник радова са: Теоријски, методолошки и методички аспекти такмичења и припреме спортиста (стр.115-121). Београд: ФСФВ.

13. Japheth, A. \& Hughes, M. (2001). The playing patterns of France and their opponents in the World Cup for association football, 1998, and the Championships, 2000. In M.D. Hughes \& I.M. Franks (Eds.), Pass.com: Computer Science and Sport III \& Performance of Sport V (pp. 277-284). Cardiff: University of Wales Institute. 
14. Jones, P., James, N. \& Mellalieu, S.D. (2004). Possession as a Performance Indicator in Soccer. International Journal of Performance Analysis in Sport, 4(1), 98-102.

15. Lago, C. (2009). The influence of match location, quality of opposition, and match status on possession strategies in professional association football. Journal of Sports Sciences, 7(13),1463 -1469 .

16. Lago, C. \& Martin, R. (2007). Determinants of possession of the ball in soccer. Journal of Sports Sciences, 25(9), 969 - 974.

17. Lago, C., Lago, J., Dellal, A. \& Gomez, M. (2010). Game-related statistics that discriminated winning, drawing and losing teams from the Spanish soccer league. Journal of Sports Science and Medicine, 9(2), 288-293.

18. Luhtanen, P., Belinskij, A., Häyrinen, M. \& Vänttinen, T. (2001). A comparative tournament analysis between EURO 1996 and 2000 in soccer. International Journal of Performance Analysis in Sport, 1(1), 74-82.

19. Rampinini, E., Impellizzeri, F.M., Castagna, C., Coutts, A.J. \& Wisloff, U. (2009). Technical performance during soccer matches of the Italian Serie A league: Effect of fatigue and competitive level. Journal of Science and Medicine in Sport, 12(1), 227-233.

20. Roxburg, A. (2008). Technical report EURO 2008. Nyon: UEFA's Football Development Division.

21. Scoulding, A., James, N. \& Taylor, J. (2004). Passing in the soccer World Cup 2002. International Journal of Performance Analysis in Sport, 4(2), 36-41.

22. Szwarc, A. (2004). Effectiveness of Brazilian and German teams and the teams defeated by team during the 17th FIFA World Cup. Kinesiology, 36(1), 83-89.
23. Szwarc, A. (2007). Efficacy of Successful and Unsuccessful Soccer Teams Taking Part in Finals of Champions League. Research Yearbook, 13(2), 221-225.

24. Szwarc, A. (2008). The Model illustrating the efficiency of actions in the soccer game. Research Yearbook. Medsportpress, 14( 2), 7477.

25. Taylor, J.B., Mellalieu, S.D., James, N. \& Sheraer, D. (2008). The influence of match location, qualify of opposition and match status on technical performance in professional association football. Journal of Sports Sciences, 26(9), 885-895.

26. Hook, C. \& Hughes, M. (2001). Patterns of play leading to shots in 'Euro 2000'. In: Pass.com. Ed: CPA (Center for Performance Analysis). Cardiff: UWIC. 295-302.

27. Hughes, M. \& Franks, I. (2005). Analysis of passing sequences, shots and goals in soccer. Journal of Sport Sciences, 23(5), 509-514.

28. Hughes, M., Robertson, K. \& Nicholson, A. (1988). Comparison of patterns of play of successful and unsuccessful teams in the 1986 World Cup for soccer. In T. Reilly, A. Lees, K. Davids, W.J. Murphy, (Eds) Science and Football, (pp. 363-367). London: E. \& F. Spon.

29. Carling, C., Williams, A.M. \& Reilly, T. (2005). Handbook of soccer match analysis. A sistematic approach to improving performance. London: Routledge

30. www.uefa.com (17. септембар 2010. године)

31. www.fifa.com (24. септембар 2010. године) 